\title{
Detection of human parvovirus B19 in cases of hydrops fetalis in São Paulo, Brazil
}

\author{
Detecção de parvovirus humano B19 em casos de hydropsia fetal em São Paulo, Brasil
}

Cristina Adelaide Figueiredo'; Maria Isabel de Oliveira²; Ana Maria Sardinha Afonso3; Joelma Queiroz Andrade4; Maria de Lourdes Brizot $^{5}$; Marcelo Zugaib ${ }^{6}$; Suely Pires Curti ${ }^{7}$

\section{key words}

Human parvovirus B19

Prenatal diagnosis

Hydrops fetalis

Ultrasound

\section{abstract}

Human parvovirus B19 infection is known to be one of the causes of hydrops fetalis. The maternal infection caused by the virus may be symptomatic or asymptomatic. In this study, 40 pregnant women with gestational age of approximately 25 weeks, prenatal diagnosis of non immune hydrops fetalis and suspected of human parvovirus B19 infection were studied between January 1999 and December 2005. Serology results and detection of DNA in the maternal serum, foetal serum and amniotic fluid confirmed that 20 pregnant women had been infected by human parvovirus B19. The ultrasound examination demonstrated foetal hydrops, anaemia, hepatosplenomegaly, ascites, cardiopathy and amniotic fluid disorders. Among the positive cases, there were three fatal losses, one by miscarriage and two by intrauterine foetal death.

\section{resumo}

A infecção por parvovírus humano B19 é um dos responsáveis pela hidropsia fetal. A infecção materna causada pelo vírus pode ser sintomática ou assintomática. Neste estudo 40 mulheres com idade gestacional de aproximadamente 25 semanas, diagnóstico pré-natal de hidropsia fetal e suspeita de infecção por parvovírus humano B19 foram avaliadas durante o período de janeiro de 1999 a dezembro de 2005. Os resultados de sorologia e detecção de DNA no soro materno, fetal e fluido amniótico confirmaram 20 mulheres grávidas com infecção por parvovírus humano B19. A análise de ultra-som demonstrou hidropsia fetal, anemia, hepatosplenomegalia, ascite, cardiopatia e desordens amnióticas. Entre os casos positivos, ocorreram três perdas fetais: uma por aborto e duas por morte fetal intra-uterina.

\section{unitermos}

Parvovírus humano B19

Diagnóstico pré-natal

Hidropsia fetal

Ultra-som

1. Mestra em Biologia Molecular; pesquisadora científica do Instituto Adolfo Lutz.

2. Doutora em Ciências; pesquisadora científica do Instituto Adolfo Lutz.

3. Especialista em Microbiologia; pesquisadora científica do Instituto Adolfo Lutz.

4. Doutora em Medicina; médica assistente da Clínica Obstétrica do Hospital das Clínicas da Faculdade de Medicina da Universidade de São Paulo (HC/FMUSP).

5. Doutora em Medicina Fetal; médica assistente da Clínica Obstétrica do HC/FMUSP.

6. Professor titular de Obstetrícia do Departamento de Obstetrícia e Ginecologia da FMUSP.

7. Doutora em Ciências; pesquisadora científica do Instituto Adolfo Lutz. 


\section{Introduction}

Human parvovirus B19 (HPVB19) is a small, nonenveloped desoxyribonucleic acid (DNA) virus that exclusively infects humans ${ }^{(4)}$. After infection, parvovirus B19 replication occurs primarily in erythrocytes and erythroblasts, which can lead to anaemia in predisposed individuals ${ }^{(5,23)}$. Infected healthy adults generally have only mild constitutional symptoms. In contrast, fetal parvovirus B19 is a congenital disorder that is characterized by non-immune hydrops (IUFD), ascites, pleural effusion, hypertrophic cardiomyopathy, placentomegaly, ventriculomegaly, and other findings caused by transplacental transmission of parvovirus to the fetus ${ }^{(6,12,14)}$. The yearly peak incidence of infection occurs during spring and epidemics occur every four years ${ }^{(23)}$. The prevalence of immunoglobulin $\mathrm{G}(\mathrm{lgG})$ antibodies directed against $B 19$ virus (B19V) in the population ranges from $2 \%$ to $15 \%$ in 1 - to 5 -year-old children; $15 \%-60 \%$ in 6 - to 19 year-old children; $30 \%-60 \%$ in adults and more than $85 \%$ in the geriatric population ${ }^{(12)}$. Hutataco et al. ${ }^{(13)}$, reported in Caieiras, São Paulo, Brazil, that seroprevalence of $72 \%$ was observed in adults (31-40 years). In Rio de Janeiro, Brazil, seroprevalence was $71.2 \%$ in pregnant women of up to 24 weeks of gestation and $21-30$ years old; $76.4 \%$ in 31- to 40-year-old women; and $72.7 \%$ in women older than 41 years ${ }^{(19)}$. The incidence of acute B19V infection in pregnancy is approximately $1 \%-2 \%$ in endemic periods, but in epidemic periods infection rate may rise to $>10 \%(7,21)$. The peak incidence of $\mathrm{B} 19 \mathrm{~V}$-associated hydrops fetalis is between 17 and 24 weeks of gestation ${ }^{(10,12)}$. A fetus affected by B19V may show signs of hydrops fetalis on ultrasound investigation, typically marked ascites, cardiomegaly and pericardial effusion. In advanced stages, generalized edema and a thick hydropic placenta can be found. In many cases, the diagnosis of foetal parvovirus B19 infection is usually made only after the finding of fetal hydrops. Cases of fetal death due to HPV B19 infection have been described mostly between 20 and 24 weeks of gestation, but cases of IUFD as early as 10 weeks and as late as 41 weeks gestation have also been described ${ }^{(3,16)}$. The interval between HPV B19 infection and development of non-immune hydrops fetalis (NIHF) ranges from two to six weeks ${ }^{(2,11,14,22)}$. The rapid correction of anaemia by in uterus transfusion of packed erythrocytes largely prevents fetal death ${ }^{(2,16)}$. The infection by parvovirus B19 is diagnosed by the detection of IgM antibodies in both maternal and fetal blood, but in some cases, maternal anti B19-IgM can no longer be detected when hydrops fetalis develops. In most of the reported cases, DNA detection in fetal tissues is the method of choice for diagnosis ${ }^{(8)}$. We hereby report the results of HPV B19 detection in maternal and fetal samples from non-immune hydrops fetalis.

\section{Material and methods}

This was a retrospective study of 40 pregnancies with a median gestational age of 25 weeks and with alterations in their ultrasonography from to the fetal medicine unit at Hospital das Clínicas da Faculdade de Medicina da Universidade de São Paulo (FMUSP) for possible parvovirus B19 exposure between 1999 and 2005 in São Paulo, Brazil. The patients were monitored with ultrasounds, and hydrops fetalis was characterized by one or more clinical signs, such as peripheral edema, ascites, anaemia and congestive heart failure. The gestational week (GW) was based on the last menstruation date, ultrasonographic and postnatal classification methods. The evaluation of possible exposure to parvovirus B19 (as well as specific information regarding the nature of the exposure) and clinical symptoms, such as facial rash, body rash, fever, runny nose, cough, joint pain, general fatigue and lymphadenopathy, were collected using a computerized database maintained at our institution. The samples were analyzed at the Adolfo Lutz Institute, São Paulo. In this study, the following were processed: 40 maternal serum samples; 15 foetal cord blood and 29 amniotic fluid samples. All mothers were subjected to cytogenetic analysis.

\section{Serology}

The samples were tested by a commercial enzyme-linked immunosorbent assay (ELISA) kit for the detectation of B19 immunoglobulin $\mathrm{M}$ (IgM) antibodies using recombinant capsid protein VP2 as antigen (Biotrin International Ltd.).

\section{Amplification by nested PCR}

Polymerase chain reaction (PCR) assay was carried out as described by Durigon ${ }^{(9)}$. For PCR, the oligonucleotide primers used were P1 (5' AAT ACA CTG TGG TIT TAT GGG CCG $3^{\prime}$ ) and P6 (5' CCA TTG CTG GTT ATA ACC ACA GGT 3'), nucleotide sequences 1399-1422 and 1682-1659, respectively. For nested PCR, the oligonucleotide primers used were P2 $\left(5^{\prime}\right.$ CCA TTG CTG GTT ATA ACC ACA GGT $3^{\prime}$ ) and P5 (5' CTAAAA ATG GCT TIT GCA GCT TCT AC $3^{\prime}$ ), nucleotide sequences 
1498-1525 and 1600-1576, respectively. The extracted DNA $(10 \mu \mathrm{l})$ was added to the PCR mixture containing $10 \mu \mathrm{l}$ of 10X reaction buffer (Applied Biosystems, Foster City, CA, USA); $200 \mu \mathrm{M}$ each dATP, dCTP, dGTP, dTTP; $0.5 \mu \mathrm{M}$ each oligonucleotide primer, and $2.5 \mathrm{U}$ of Taq polymerase (Applied Biosystems Foster City, CA, USA). After the first amplification, the second (nested) PCR was carried out and $10 \mu \mathrm{l}$ of the first PCR product was added to the nested PCR mix using the specific primers and put into in Applied Biosystems Thermocycler with the following cycle definitions: $94^{\circ} \mathrm{C} / 5$ minutes; $95^{\circ} \mathrm{C} / 45$ seconds; $55^{\circ} \mathrm{C} / 1$ minute, $72^{\circ} \mathrm{C} / 1.5$ minute $(35$ repetitions after second step) and finally, $72^{\circ} \mathrm{C}$ for five minutes, obtaining a 102bp fragment. The amplified products were submitted to $1.5 \%$ agarose gel electrophoresis and ethidium bromide staining PCR products were visualized on ethidium-stained agarose gel. The negative control was processed in parallel with water as a template.

\section{Results}

Among 40 pregnant women with diagnosis of hydrops fetalis, 20 cases were confirmed to be infected with HPV B19 by the detection of DNA in maternal and fetal sera and/or amniotic fluid. B19 DNA was detected in 19 maternal sera, 10 fetal sera and 13 amniotic fluid specimens. IgM antibodies to parvovirus were positive in 15 maternal and 10 fetal sera (Table 1). The gestational age at the time of diagnosis of maternal among the women was 22 and 25 weeks (Table 1). The sources of the infections were unknown in all the studied cases, and $60 \%$ of the mothers did not report prodromal symptoms as sore throat, low grade fever, adenopathies (cervical and/or axillary) and/or malaise. The chromosome karyotype was a normal 46, XX. Pregnancy outcomes are also described in Table 1. Among the fetuses, three that survived were concomitantly diagnosed as fetal anaemia

Table 1 Laboratory features in cases positive for parvovirus HPV B19

HPV B19 detection

$\begin{array}{lccccccccc}\text { Case number } & \begin{array}{c}\text { Gestational } \\ \text { age }\end{array} & \begin{array}{c}\text { Maternal } \\ \text { IgM }\end{array} & \begin{array}{c}\text { Serum } \\ \text { DNA }\end{array} & \text { Fetal IgM } & \begin{array}{c}\text { Serum } \\ \text { DNA }\end{array} & \begin{array}{c}\text { Amniotic } \\ \text { fluid DNA }\end{array} & \text { IUT } & \text { Intrauterine } & \text { Pregnancy } \\ 1 & 22 & (-) & (+) & (+) & (+) & \text { NP } & \text { Not } & \text { Not } & \text { Yes } \\ 2 & 22 & (-) & (+) & (+) & (+) & \text { NP } & \text { Not } & \text { Not } & \text { Yes } \\ 3 & 22 & (+) & (+) & \text { NP } & \text { NP } & (+) & \text { Yes } & \text { Yes } & \text { Not } \\ 4 & 22 & (+) & (+) & \text { NP } & \text { NP } & (+) & \text { Not } & \text { Not } & \text { Yes } \\ 5 & 22 & (+) & (+) & \text { NP } & \text { NP } & (+) & \text { Not } & \text { Not } & \text { Yes } \\ 6 & 23 & (+) & (+) & (+) & (+) & \text { NP } & \text { Not } & \text { Not } & \text { Yes } \\ 7 & 23 & (-) & (+) & (+) & (+) & \text { NP } & \text { Not } & \text { Yes } & \text { Not } \\ 8 & 23 & (+) & (+) & (+) & (+) & \text { NP } & \text { Yes } & \text { Not } & \text { Yes } \\ 9 & 23 & (+) & (+) & \text { NP } & \text { NP } & (+) & \text { Not } & \text { Not } & \text { Yes } \\ 10 & 23 & (+) & (+) & \text { NP } & \text { NP } & (+) & \text { Not } & \text { Not } & \text { Yes } \\ 11 & 24 & (-) & \text { NP } & (+) & (+) & (+) & \text { Not } & \text { Not } & \text { Yes } \\ 12 & 24 & (-) & (+) & \text { NP } & \text { NP } & (+) & \text { Not } & \text { Not } & \text { Yes } \\ 13 & 24 & (+) & (+) & \text { NP } & \text { NP } & (+) & \text { Not } & \text { Not } & \text { Yes } \\ 14 & 24 & (+) & (+) & (+) & (+) & (+) & \text { Not } & \text { Not } & \text { Yes } \\ 15 & 25 & (+) & (+) & \text { NP } & \text { NP } & (+) & \text { Not } & \text { Not } & \text { Yes } \\ 16 & 25 & (+) & (+) & (+) & (+) & \text { NP } & \text { Not } & \text { Not } & \text { Yes } \\ 17 & 25 & (+) & (+) & \text { NP } & \text { NP } & (+) & \text { Not } & \text { Yes } & \text { Not } \\ 18 & 25 & (+) & (+) & (+) & (+) & \text { NP } & \text { Not } & \text { Not } & \text { Yes } \\ 19 & 25 & (+) & (+) & (+) & (+) & (+) & \text { Yes } & \text { Not } & \text { Yes } \\ 20 & 25 & (+) & (+) & \text { NP } & \text { NP } & (+) & \text { Not } & \text { Not } & \text { Yes }\end{array}$

NP: not performed; IUT: intrauterine transfusion. 
and intrauterine blood was supplied (Table 1). Cases 3 and 19 received one intrauterine transfusion and in case 8 , the fetus showed severe anaemia and three blood transfusions had to be carried out. Among the three fetal deaths, two were the aforementioned cases with hydrops and severe anaemia and one was a miscarriage. All three cases were serologically negative for the toxoplasmosis, rubella virus, cytomegalovirus, herpes simplex virus (TORCH) syndrome. The frequency of cases demonstrated a substantial variation during the year (Table 2).

\begin{tabular}{ccl} 
Table 2 & $\begin{array}{c}\text { Cases of hydrops fetalis from } 1999 \text { to } \\
\text { 2005 tested for detection of human } \\
\text { parvovirus B19 }\end{array}$ \\
\hline Year & Total pos/neg & Fetal abnormalities \\
1999 & $6(3 / 3)$ & All cases with hydrops, \\
2000 & $8(6 / 2)$ & 15 of them with anemia, \\
2001 & $6(3 / 3)$ & one of them with \\
2002 & $4(2 / 2)$ & hepatoesplenomegaly \\
2003 & $4(2 / 2)$ & and one with \\
2004 & $6(2 / 4)$ & cardiopathy \\
2005 & $6(2 / 4)$ & \\
\hline
\end{tabular}

\section{Discussion}

Parvovirus infection is one of the leading causes of IUFD in neonates. Parvovirus infects the fetal liver, which is the site of erythrocyte production during early development leading to fetal anemia. The most common clinical manifestation of fetal anemia is hydrops, which is observed sonographically as skin edema, ascites, pleural effusion, placentomegaly and polyhydramnios ${ }^{(6,14,23)}$. Most cases of hydrops are due to fetal aplastic anaemia, which leads to high-outpout cardiac failure and myocarditis ${ }^{(2,5)}$.

We studied the occurrence of HPV B19 infection in maternal and fetal samples of cases with non-immune hydrops fetalis. In the present study, 20 of the 40 cases were positive to parvovirus B19. Among the positive cases, IgM antibodies to parvovirus were detected in 15 maternal and 10 fetal sera. The absence of B19 lgM in maternal blood at the time of B19-induced hydrops has been reported in several studies; in general, IgM detection rates in those studies varied widely: $41 \%{ }^{(10) ;} 45 \%{ }^{(20)} ; 52.9 \%{ }^{(24)}$ and $81.3 \%{ }^{(8)}$. Enders et al. ${ }^{(10)}$ reported that acute infection was demonstrated by
IgM antibody detection in 55 pregnant women $(32 \%$ of them in the first trimester, $54 \%$ in the second, and $14 \%$ in the third). In contrast, HPV B19 IgM and DNA were detected in all samples of fetal cord blood analyzed and the number of positive IgM in fetal samples was high when compared with other published data ${ }^{(8,24)}$. Using standard procedures, detection of HPV B19 specific IgM in fetal blood has a sensitivity of $29 \%$ compared to almost $100 \%$ for $\mathrm{PCR}^{(1,10)}$. However, low HPV B19 DNA levels may persist for years after acute infection and, therefore, low positive PCR results for HPV B19 do not prove recent infection ${ }^{(15)}$.

The cases of parvovirus B19 reported in this study occurred in different years, and the majority of the positive cases occurred during the period 1999-2001. In addition, during the years 1999 and 2000, an outbreak of erythema infectiosum was identified in four states in Brazil (São Paulo, Paraná, Santa Catarina and Rio Grande do Sul) and was investigated by us at Instituto Adolfo Lutz ${ }^{(18)}$. The clinical manifestations of HPV B19 infection in pregnant women are different from that in non-pregnant women. Previous reports have shown that $30 \%-60 \%$ maternal HPV B19 infection is entirely asymptomatic ${ }^{(9,16)}$, which is in good agreement with our finding of $60 \%$ asymptomatic patients. Enders ${ }^{(8)}$ reported that there was no association between the presence of maternal symptoms and the incidence of non-hydropic fetal death or hydrops fetalis, although the presence of rash and/or arthropathy between 9 and 16 weeks of gestation was associated with an increased risk on non-hydropic fetal death. According to different prospective studies, the risk of developing hydrops fetalis varied between $0 \%$ and $12.5 \%$ with a maximum of $7.1 \%$ when infection occurred between 13 and 20 gestational weeks. The overall rate of parvovirus B19-related fetal loss has been estimated as between $4 \%$ and $16 \%$ with a peak frequency during the early second trimester, as seen in three of our cases. The mechanism involved in the fetal loss is explained by the tropism of HPV B19 for immature erythropoietic cells, a substantial increase in haemopoiesis at that gestational age, and low anaemia tolerance due to small haematological reserves $(3,10,12)$. Although the replication of parvovirus B19 usually occurs in red blood precursors, recent studies have shown that this virus can also infect myocardial cells and thus contribute to heart failure ${ }^{(17)}$. Between the studied cases, intrauterine transfusion of packed erythrocytes was made in three fetuses that developed cardiorespiratory insufficiency in association with severe anaemia. Management of B19V infection with intrauterine transfusion (IUT) can correct fetal anaemia and may reduce the mortality of B19V infection significantly. Timely IUT of 
fetuses with severe hydrops reduces the risk of fetal death ${ }^{(10)}$. In most cases, one transfusion is sufficient for fetal recovery. Following successful transfusion, it may take weeks for all hydropic signs to disappear. A few cases of spontaneous resolution of hydrops due to parvovirus infection have been described. This has led to the discussion of the best time to intervene or whether to intervene at all. Only fetal blood sampling can provide information on fetal haemoglobin and reticulocyte count, and thus on whether the fetus may be in a spontaneous recovery phase or not. Furthermore, adequate monitoring by ultrasound and Doppler are necessary for timely recognition of possible fetal complications. In Brazil, because of the reduction in rubella incidence rates after the introduction of national mass vaccination campaigns, HPV B19 infection has increased in importance, particularly in children and pregnant women.

\section{References}

1. BEEERSMA, M. F. C. et al. Parvovirus B19 viral loads in relation to VP1 and VP2 antibody responses in diagnostic blood samples. J Clin Virol, v. 34, p. 71-5, 2005.

2. BOUSQUET, F. et al. B19 parvovirus-induced fetal hydrops: good outcome after intrauterine blood transfusion at 18 weeks of gestation. Fetal Diagn Ther, v. 13, p. 132-3, 2000.

3. BROLIDEN, K. et al. Clinical aspects of parvovirus B19 infection. J Intern Med, v. 260, p. 285-304, 2006.

4. COSSART, Y. E. A. et al. Parvovirus-like particles in human sera. Lancet, v. 1, p.72-3, 1975.

5. CHISAKA, H. et al. Parvovirus B19 and the pathogenesis of anemia. Rev Med Virol, v. 13, p.347-59, 2003.

6. CRANE, J. Parvovirus B19 infection in pregnancy. J Obstet Gynaecol Can, v. 24, n. 9, p. 727-43, 2002.

7. DEMBINSKI, J. et al. Long-term follow-up of serostatus after maternofetal parvovirus B19 infection. Arch Dis Child, v. 88 , p. $219-21.2003$.

8. DIECK, D. et al. Prenatal diagnosis of congenital parvovirus B19 infection: value of serological and PCR techniques in maternal and fetal serum. Prenat Diag, v. 19, n. 12, p. 1119-23,1999.

9. DURIGON, E. L. Multiple primer pairs for polymerase chain reaction (PCR) amplification of human parvovirus B19 DNA. J Virol Methods, v. 44, p. 155-65, 1993.

10. ENDERS, M. et al. Fetal morbidity and mortality after acute human parvovirus B19 infection in pregnancy: prospective evaluation of 1,018 cases. Prenat Diagn, v. 24, p. 513-8, 2004.

11. HARPER, J. H. et al. Prospective evaluation of 618 pregnant women exposed to parvovirus B19: risks and symptoms. Obstet Gynecol, v. 91, n.3, p. 413-20, 1998.

12. HEEGAARD. E. D.; BROWN, K. E. Human parvovirus B19. Clin Microbiol Rev, v. 15, p. 485-505, 2002.

13. HUATUCO, E. M. M. et al. Seroprevalence of human parvovirus B19 in a suburban population in São Paulo, Brazil. Rev Saúde Pública, v. 3, p. 443-9, 2008.
14. JONG, E. P. et al. Parvovirus B19 infection in pregnancy. J Clin Virol, v. 36, n. 1, p.1-7, 2006.

15. LINDBLOM, A. et al. Slow clearance of human parvovirus B19 viremia following acute infection. Clin Infect Dis, v. 41, n. 8, p.1201-3, 2005.

16. NORBECK, O. et al. Revised clinical presentation of parvovirus B19 associate intrauterine fetal death. Clin Infect Dis, v. 35, n. 9, p. 1032-8, 2002.

17. O'MALLEY, A. et al. Parvovirus infect cardiac myocytes in hydrops fetalis. Pediatr Dev Pathol, v. 6, p. 414-20, 2003.

18. OLIVEIRA, M. I. et al. Parvovirus B19 infection in Brazil, during an outbreak in Paraná, Santa Catarina, Rio Grande do Sul and São Paulo. In: XIII National Meeting of Virology, Águas de Lindóia, 2002. Abstract. p. 143.

19. SILVA, A. R. A. et al. Prevalência de anticorpos IgG antiparvovírus B19 em gestantes durante o atendimento pré-natal e casos de hidropisia fetal não-imune atribuídos ao parvovírus B19, na cidade do Rio de Janeiro. Rev.Soc Bras Med Trop, v. 39, n. 5, p.46772, 2006.

20. SEARLE, K. et al. Development of antibodies to the nonstructural protein NS1 of parvovirus B19 during acute symptomatic and subclinical infection in pregnancy: complications for pathogenesis doubtful. Med Virol, v. 56, n. 3, p. 192-8, 1998.

21. TROTTA, M. et al. Intrauterine parvovirus B19 infection: early prenatal diagnosis is possible. Int J Infect Dis, v. 8, p. 130-1, 2004.

22. YAEGASHI, N. et al. The incidence of, and factors leading to, parvovirus B19-related hydrops fetalis following maternal infection: report of 10 cases and metaanalysis. J Infect, v. 37, n. 1, p. 28-35, 1998.

23. YOUNG, N. S.; BROWN, K. E. Parvovirus B19. N Engl J Med, v. 350, p. 586-97, 2004.

24. ZERBINI, M. et al. Comparative evaluation of virological and serological methods in prenatal diagnosis of parvovirus B19 fetal hydrops. J Clin Microbiol, v. 34, n.3, p. 603-8, 1996.

\begin{tabular}{l|l} 
Mailing adress \\
\hline Cristina Adelaide Figueiredo \\
Instituto Adolfo Lutz \\
Setor de Virologia, Seção de Vírus Produtores de Exantemas \\
Av. Dr.Arnaldo, 355 \\
CEP. 01246-902 - São Paulo-SP
\end{tabular}

